\title{
Members of the Society Will Receive a Critical Guide to Business History
}

A volume by Henrietta M. Larson, entitled Guide to Business History: Materials for the Study of American Business History and Suggestions for Their Use, has just appeared as a number in the Harvard Studies in Business History. About five thousand publications are cited, with comments on almost every item showing the scope of its value or usefulness. The list includes books and articles with indirect as well as obvious bearing on the general subject. They are so grouped, with introductory notes, as to constitute an outline of the fundamental ideas and concepts which are developing in the field of business history. Designed primarily for those working in that field, the book will be valuable also to economic, political, and social historians, to economists, to sociologists, and to students of business in its broader aspects. A full and analytical index by Elsie H. Bishop gives practical assistance in the use of the Guide.

Professor Larson brought to the task of compiling the Guide a broad knowledge of social and economic history and long experienct in the use of the materials for study in these fields, as well as an almost pioneering knowledge of the sources upon which the study of business history is based.

Although the author has given some attention to the function of government in business, she has dealt almost entirely with private business. She has placed emphasis upon the value of biographical material which reveals the work of individual business men. Among many topics which have never before been given adequate consideration, she has stressed the important rôle played by the executive throughout the long annals of business. As she says:

In recognizing the wide ramifications of business it is important to remember that business is in the final analysis the work of individual men working in separate and independent units, or companies, and that the most significant figure or figures in the unit are the administrator or administrators. This emphasis on the administrator does not suggest a narrow conception of business; it points to the great reality that in the 
administrator is brought together that whole sum of factors, conditions, influences, relationships, and operations which affect or are a part of the functioning of the business unit and thus of the system. His function, then, that of administration, is the central or coördinating function in business.

\section{Request for a Volume of Harvard Studies in Business History}

Owing to a constantly increasing interest in the Harvard Studies in Business History, certain titles become out of print from time to time. At present there is a shortage of Development of Two Bank Groups in the Central Northwest: A Study in Bank Policy and Organization by Charles Sterling Popple. If any member has a clean copy in good condition, for which he no longer has any use, the Executive Secretary would appreciate being given an opportunity to purchase it at list price $(\$ 4.00)$ for the Society's use. 